\title{
CONVERSION OF CERRADO INTO AGRICULTURAL LAND IN THE SOUTH-WESTERN AMAZON: CARBON STOCKS AND SOIL FERTILITY
}

João Luís Nunes Carvalho ${ }^{1}$; Carlos Eduardo Pelegrino Cerri²; Brigitte Josefine Feigl ${ }^{3}$; Marisa de Cássia Píccolo ${ }^{3}$; Vicente de Paula Godinho4; Uwe Herpin ${ }^{5}$; Carlos Clemente Cerri $^{3 *}$

${ }^{I}$ USP/ESALQ - Programa de Pós-Graduação em Solos e Nutrição de Plantas.

${ }_{3}^{2} U S P / E S A L Q$ - Depto. de Ciência do Solo, C.P. 09 - 13418-900 - Piracicaba, SP - Brasil. ${ }^{3}$ USP/CENA - Lab. de Biogeoquímica Ambiental, C.P. 96 - 13400-970 - Piracicaba, SP - Brasil.

${ }_{5}^{4}$ Embrapa Rondônia, C.P. 406 - 78995-000 - Vilhena, RO - Brasil.

${ }_{5}^{5}$ USP/ESALQ/NUPEGEL, C.P. 09 - 13418-900 - Piracicaba, SP - Brasil.

*Corresponding author <cerri@cena.usp.br>

ABSTRACT: Land use change and land management practices can modify soil carbon (C) dynamics and soil fertility. This study evaluated the effect of tillage systems (no-tillage - NT and conventional tillage - CT) on soil C and nutrient stocks in an Oxisol from an Amazonian cerrado following land use change. The study also identified relationships between these stocks and other soil attributes. Carbon, $\mathrm{P}, \mathrm{K}, \mathrm{Ca}$ and $\mathrm{Mg}$ stocks, adjusted to the equivalent soil mass in the cerrado (CE), were higher under NT. After adoption of all but one of the NT treatments, $\mathrm{C}$ stocks were higher than they were in the other areas we considered. Correlations between $\mathrm{C}$ and nutrient stocks showed positive correlations with $\mathrm{Ca}$ and $\mathrm{Mg}$ under NT due to continuous liming, higher crop residue inputs and lack of soil disturbance, associated with positive correlations with cation exchange capacity (CEC), base saturation and $\mathrm{pH}$. The positive correlation $(\mathrm{r}=0.91, p<0.05)$ between $\mathrm{C}$ stocks and CEC in the $\mathrm{CE}$ indicates the important contribution of soil organic matter (SOM) to CEC in tropical soils, although the exchange sites are under natural conditions - mainly occupied by $\mathrm{H}$ and $\mathrm{Al}$. Phosphorus and $\mathrm{K}$ stocks showed positive correlations ( 0.81 and 0.82 , respectively) with $\mathrm{C}$ stocks in the $\mathrm{CE}$, indicating the direct relationship of $\mathrm{P}$ and $\mathrm{K}$ with $\mathrm{SOM}$ in natural ecosystems. The high spatial variability of $\mathrm{P}$ and $\mathrm{K}$ fertilizer application may be obscuring these soil nutrient stocks. In this study, the main source of $\mathrm{P}$ and $\mathrm{K}$ was fertilizer rather than SOM.

Key words: Oxisol, no-tillage, conventional tillage, nutrient stock

\section{CONVERSÃO DO CERRADO EM AGRICULTURA NO SUDOESTE DA AMAZÔNIA: ESTOQUES DE CARBONO E FERTILIDADE DO SOLO}

RESUMO: Mudanças de uso da terra e práticas de manejo modificam a dinâmica do $\mathrm{C}$ e a fertilidade do solo. Este estudo avaliou as implicações dos sistemas de cultivo (NT e CT) nos estoques de C e de nutrientes e identificou inter-relações entre estes estoques e outros atributos da fertilidade do solo em Latossolo após a mudança do uso da terra no cerrado amazônico. Os estoques de $\mathrm{C}$ e de nutrientes ( $\mathrm{P}, \mathrm{K}, \mathrm{Ca}$ e $\mathrm{Mg}$ ) ajustados pela massa equivalente do solo sob cerrado (CE), foram maiores principalmente sob NT. Após a adoção do NT, exceto em 2NT, os estoques de C foram maiores em relação às demais áreas avaliadas. Correlações entre estoques de $\mathrm{C}$ e de nutrientes revelaram algumas correlações positivas com $\mathrm{Ca}$ e $\mathrm{Mg}$ nas áreas sob NT, devido ao uso continuo de calcário, à maior quantidade de resíduos culturais e ao não revolvimento do solo, associado à correlações positivas com CTC, saturação por bases e $\mathrm{pH}$. A correlação positiva $(\mathrm{r}=0,91, p<0,05)$ entre estoques de C e CTC em CE indica a importante contribuição da MOS na CTC de solos tropicais, embora os sítios de troca estejam ocupados principalmente por $\mathrm{H}+\mathrm{Al}$. Estoques de $\mathrm{P}$ e $\mathrm{K}$ mostraram correlações positivas com estoques de C em CE (0,81 e 0,82; respectivamente), indicando a alta relação de $\mathrm{P}$ e $\mathrm{K}$ com a MOS em ecossistemas naturais. A alta variabilidade espacial associada à aplicação de fertilizantes ( $\mathrm{P}$ e K) no sulco de plantio pode ter mascarado os resultados dos estoques. A principal fonte destes nutrientes para o solo foi o fertilizante aplicado e não a MOS.

Palavras-chave: Latossolo, plantio direto, plantio convencional, estoque de nutrientes 


\section{INTRODUCTION}

The conversion of the Amazon cerrado into agricultural land through deforestation and the burning of natural vegetation generally results in a reduction of soil organic matter (SOM) (Cerri et al., 2007; Green et al., 2007). The reduction in SOM that follows cultivation has both a direct and an indirect influence on other soil chemical attributes (Carvalho et al., 2007; Bustamante et al., 2006). The SOM has many functions and its relative importance varies according to the different soils, climates and land uses (Bernardi et al., 2007).

Generally, the increase in SOM results in increases in soil cation exchange capacity (CEC) (Bayer \& Mielniczuk, 1997) and in the availability of $P$ and other plant nutrients. Most cerrado soils are dominated by low activity clays, with low inherent availability of nutrients and high acidity, therefore the importance of SOM for an adequate and sustainable system is a fundamental concern (Roscoe, 2005; Bustamante et al., 2006). Adequate management systems are required to increase C stocks in the soil (Franchini et al., 2007) and to enhance soil fertility.

The adoption of no-tillage (NT) reduces SOM decomposition rate leading to its maintenance and accumulation (Bayer \& Mielniczuk, 1999; Resck et al., 2000). Moreover, when NT is associated with a crop rotation with more than one crop per year and fertilizer applications, it may lead to a higher input of residues and nutrients. However, information on $\mathrm{C}$ accumulation rates in soil under NT is inconclusive. Several studies have shown C increase under NT (Corazza et al., 1999; Bayer et al., 2004; Oliveira et al., 2004; Bernoux et al., 2006; Cerri et al., 2007), while others reported no differences in relation to native cerrado or a CT system (Freitas et al., 2000; Roscoe \& Buurman, 2003). Soil fertility usually increases with fertilizer application, but its relationship with $\mathrm{C}$ stocks is unclear for the Brazilian Cerrado region.

Therefore, the objective of this study was to evaluate implications of different tillage systems (NT and $\mathrm{CT}$ ) on soil $\mathrm{C}$ and nutrient stocks in an Oxisol following land use change in the Amazon cerrado and to identify relationships between these stocks and other soil fertility attributes.

\section{MATERIAL AND METHODS}

\section{Study Area}

The study was carried out in a 3,700 ha farm in Vilhena, Rondônia State, Brazil (12²9' S, 6000' W) which followed a farming system typical for the area. The native vegetation of the region is classified as cerrado, sub-group Cerradão (Ribeiro \& Walter, 1998). According to Köppen (1900) the climate is classified as $\mathrm{Aw}$ (humid tropical) with a mean temperature of $23.1^{\circ} \mathrm{C}$ and a minimum low temperature of $18.0^{\circ} \mathrm{C}$ during the coldest month. The region has a well defined dry season (May to September) with monthly rainfall below $10 \mathrm{~mm}$ and mean annual rainfall averaging $2,170 \mathrm{~mm}$. The mean altitude of the region is $600 \mathrm{~m}$ and the area has a gently ondulating relief. The soil is a Typic Hapludox with very fine clayey texture (730 $\mathrm{g}$ clay $\mathrm{kg}^{-1}$ of soil).

In the period 1999 to 2004, small areas of the 3,700 ha were cleared of native vegetation every year to provide new land for cultivation. The clearing was done by bulldozer tractor at the end of the rainy season (May/June). After leaving the aboveground biomass drying for 20 days, it was burned. After mechanical windrowing, the areas were 'cleaned' by removing any remaining material and burning stump and root residues. In order to prepare the soil, dolomitic limestone was applied and incorporated using a disc harrow with the aim of achieving $50 \%$ base saturation in the plow layer. Subsequently, a levelling harrow was used. All the cultivated areas that we sampled had been subjected to these same preparation steps following clearing.

A specific sequence of crops and management practices that are common in this area following the clearing of the cerrado were studied. The experimental area is located within a regular farm operating as a business and was therefore not set up for scientific purposes. We evaluated a chronosequence composed of six areas under the same topographic, edaphic and climatic conditions, differing only in respect to the year of clearing for crop establishment. For each of the six areas, five pseudo replicates were established. They were considered as such because they came from the same evaluation areas.

Each newly established site of approximately 1 ha $(100 \times 100 \mathrm{~m})$ was initially seeded with rice under CT. After two years of rice under CT (with lime incorporation), which levelled and cleaned the area, a soybean crop in NT system was introduced in several areas for one to three years. In view of the cultivation schedule usually applied in this region, a chronosequence comprising of six areas was chosen for the present study: cerrado (CE) with native vegetation as a reference, two areas under the CT system cultivated with rice for one year (1CT) and two years $(2 \mathrm{CT})$, and three areas under NT system cultivated with soybean for one (1NT), two $(2 \mathrm{NT})$ and three years $(3 \mathrm{NT})$ in each case after a 2-year period of rice under CT alternating either with another crop or a fallow period in the winter (Table 1). 
Table 1 - Cultivation history of the main crops (rice, soybean) and land use in the winter season under different land use practices with annual application rates of lime and NPK fertilizer in a study area in the Amazon cerrado. (Adapted from Carvalho et al., 2007).

\begin{tabular}{|c|c|c|c|c|c|c|c|}
\hline Areas & Cultivation period & Main crop & Winter crop & Lime & $\mathrm{N}$ & $\mathrm{P}_{2} \mathrm{O}_{5}$ & $\mathrm{~K}_{2} \mathrm{O}$ \\
\hline & & & & $\mathrm{Mg} \mathrm{ha}^{-1}$ & $-\cdots$ & $\mathrm{kg} \mathrm{ha}^{-1}$ & - \\
\hline \multicolumn{8}{|c|}{ Continuous cerrado } \\
\hline $1 \mathrm{CT}$ & $2003-2004$ & rice $(\mathrm{CT})$ & fallow & 6 & 7 & 94 & 50 \\
\hline \multirow{2}{*}{$2 \mathrm{CT}$} & $2002-2003$ & rice $(\mathrm{CT})$ & fallow & 2 & 15 & 99 & 53 \\
\hline & $2003-2004$ & rice $(\mathrm{CT})$ & fallow & 4 & 15 & 99 & 53 \\
\hline \multirow{3}{*}{$1 \mathrm{NT}$} & $2001-2002$ & rice $(\mathrm{CT})$ & fallow & 2 & 33 & 86 & 66 \\
\hline & $2002-2003$ & rice $(\mathrm{CT})$ & fallow & 2 & 35 & 99 & 73 \\
\hline & $2003-2004$ & soybean $(\mathrm{NT})$ & maize & 2 & 16 & 157 & 112 \\
\hline \multirow{4}{*}{$2 \mathrm{NT}$} & $2000-2001$ & rice $(\mathrm{CT})$ & fallow & 2 & 13 & 86 & 46 \\
\hline & $2001-2002$ & rice $(\mathrm{CT})$ & fallow & 2 & 14 & 88 & 48 \\
\hline & $2002-2003$ & soybean $(\mathrm{NT})$ & sorghum & 1 & 0 & 132 & 120 \\
\hline & $2003-2004$ & soybean (NT) & millet & 1 & 0 & 101 & 96 \\
\hline \multirow{5}{*}{$3 \mathrm{NT}$} & $1999-2000$ & rice $(\mathrm{CT})$ & fallow & 1 & 14 & 88 & 48 \\
\hline & $2000-2001$ & rice $(\mathrm{CT})$ & fallow & 2 & 10 & 100 & 90 \\
\hline & $2001-2002$ & soybean $(\mathrm{NT})$ & fallow & 1 & 11 & 110 & 92 \\
\hline & $2002-2003$ & soybean $(\mathrm{NT})$ & maize & 0 & 16 & 160 & 136 \\
\hline & $2003-2004$ & soybean $(\mathrm{NT})$ & maize & 2 & 16 & 157 & 112 \\
\hline
\end{tabular}

NB 1CT and 2CT = one and two years Conventional Tillage with rice; 1NT, 2NT and 3NT = one, two, and three years No-Tillage with soybean after a 2-year period of rice under conventional tillage

\section{Soil Sampling and Chemical Analysis}

Soil sampling was carried out in July 2004 in six areas of approximately 1 ha $(100 \times 100 \mathrm{~m})$ based on a completely randomized sampling design with five pseudo replicates in each area. Soil samples were taken from five sites at $0-5 \mathrm{~cm}, 5-10 \mathrm{~cm}, 10-20 \mathrm{~cm}$ and 20-30 cm depth. For soil bulk density determination, undeformed samples were collected using a steel metal cylinder $(5 \times 5 \mathrm{~cm})$. In the $10-20 \mathrm{~cm}$ and $20-30 \mathrm{~cm}$ soil layers, the samples were taken in the middle part of the corresponding layer.

After air-drying, the samples were sieved to $<2 \mathrm{~mm}$. From each sample, $10 \mathrm{~g}$ were ground and sieved to $0.25 \mathrm{~mm}$ for determination of total organic carbon. The determination was carried according to Nelson \& Sommers (1982) using a Carbon Analyzer.

Soil $\mathrm{pH}$ was measured in a $0.01 \mathrm{M} \mathrm{CaCl}_{2}$ solution. Available $\mathrm{P}$ and exchangeable cations $\left(\mathrm{Ca}^{2+}, \mathrm{Mg}^{2+}\right.$ and $\mathrm{K}^{+}$) were extracted using ion exchange resins, according to Raij \& Quaggio (1983). Potential acidity $\left(\mathrm{H}^{+}\right.$ $\left.+\mathrm{Al}^{3+}\right)$ was determined by means of $1 \mathrm{~N}$ calcium acetate solution at $\mathrm{pH}$ 7.0, EMBRAPA (1979). Cation exchange capacity at $\mathrm{pH} 7.0$ and base saturation $(\mathrm{V})$ were obtained by the sum of the exchangeable cations $\left(\mathrm{Ca}^{2+}\right.$ $\left.+\mathrm{Mg}^{2+}+\mathrm{K}^{+}\right)$and $\left(\mathrm{H}^{+}+\mathrm{Al}^{3+}\right)$.

\section{Carbon and Nutrient Stock Calculation}

For each sampled soil layer the calculations for $\mathrm{C}$ and nutrient stocks $\left(\mathrm{Mg} \mathrm{ha}^{-1}\right)$ were carried out by multiplying the concentration of the element (\%) by the soil bulk density $\left(\mathrm{g} \mathrm{cm}^{-3}\right)$ and by the layer thickness $(\mathrm{cm})$. As the samples were collected in fixed layers, the stock calculation had to account for soil bulk density which can change according to land use. Therefore, we used the methodology described by Ellert \& Bettany (1996) to correct soil $\mathrm{C}$ stocks to an equivalent mass-depth. In our case, the soil depth of the cultivated areas that contain the same mass of soil as the corresponding layer $(0-30 \mathrm{~cm})$ in the CE (the reference) was calculated. The same strategy has been applied in several studies that evaluated differences in soil C stocks due to land use change in the Brazilian Amazon (Moraes et al., 1996; Bernoux et al., 1998; Cerri et al., 2003).

Briefly, soil layers that were equivalent to the same mass of soil in the $30 \mathrm{~cm}$ reference profile (CE), were calculated as follows: (i) the weighted mean bulk density in the corresponding soil layer in the $\mathrm{CE}\left(\mathrm{M}_{\mathrm{ce}}\right)$ was determined, (ii) the weighted mean bulk density in the corresponding soil layer in each area (1CT, 2CT, $1 \mathrm{NT}, 2 \mathrm{NT}$ and $3 \mathrm{NT})\left(\mathrm{M}_{\text {area }}\right)$ was calculated, (iii) the equivalent layer was then calculated according to equation 1.

Equivalent soil layer $(\mathrm{cm})=\left(\mathrm{M}_{\mathrm{ce}} / \mathrm{M}_{\text {area }}\right) \times 30$ 


\section{Statistical Analysis}

Soil C stocks, nutrient stocks and soil attributes from the evaluated areas were analyzed for variance (ANOVA) to determine the influence of land use and management. A Tukey's test was used to identify differences $(p \leq 0.05)$ between treatments and for all evaluated soil attributes. The Pearson's correlation coefficient was used in the six areas, each with five pseudo replicates. All statistical analyses were carried out using SAS version 6 (SAS Institute, 1989).

\section{RESULTS AND DISCUSSION}

\section{Soil Bulk Density}

The mean soil density in the $0-30 \mathrm{~cm}$ layer in the $\mathrm{CE}$ is $0.77 \mathrm{~g} \mathrm{~cm}^{-3}( \pm 0.12)$ (Figure 1). The value is low due to a large amount of litter and roots and a high $\mathrm{C}$ content in the CE soil (Carvalho et al., 2007). A mean soil density of $0.93 \mathrm{~g} \mathrm{dm}^{-3}$ was reported for a Typic Eutrudox under Cerradão in Goiás (Rosa et al., 2003). For a Typic Hapludox (650 $\mathrm{g} \mathrm{kg}^{-1}$ of clay) a mean bulk density of $0.98 \mathrm{~g} \mathrm{~cm}^{-3}$ was determined for the $0-20 \mathrm{~cm}$ soil layer under cerrado in Mato Grosso do Sul State, Brazil (Bayer et al., 2006). In a clayey Typic Hapludox under cerrado stricto sensu, Resck et al. (2000) measured a bulk density of $0.97 \mathrm{~g} \mathrm{~cm}^{-3}$ in the $0-30 \mathrm{~cm}$ layer.

Soil bulk density increased under CT, probably due to soil structural changes associated with the use of farm machinery. This finding is in agreement with Da Veiga et al. (2007). In 1CT and 2CT, the soil bulk density averaged 1.0 and $0.93 \mathrm{~g} \mathrm{~cm}^{-3}$; respectively. A bulk density of $1.06 \mathrm{~g} \mathrm{~cm}^{-3}$ was measured after 20 years of CT in a Typic Hapludox in Mato Grosso do Sul State, Brazil (Bayer et al., 2006). After NT was introduced, there was a tendency for higher soil bulk density values, with means of $1.11,0.98$ and $1.14 \mathrm{~g}$ $\mathrm{cm}^{-3}$ in $1 \mathrm{NT}, 2 \mathrm{NT}$ and $3 \mathrm{NT}$, respectively.

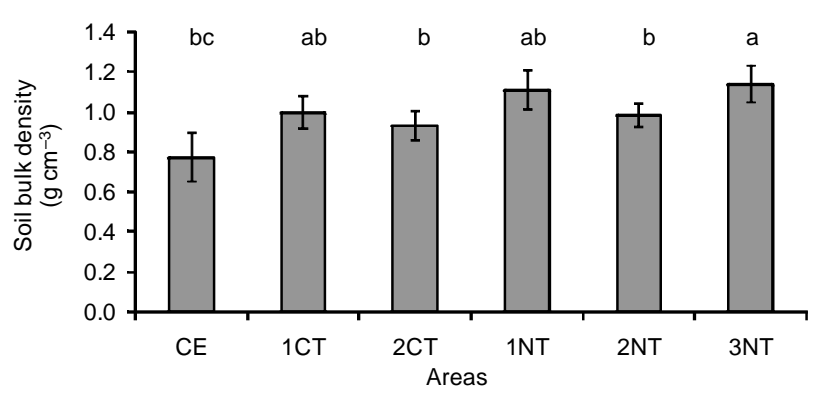

Figure 1 - Weighted means of soil bulk density in the reference soil layer in the cerrado (CE) and the equivalent soil layers after one and two years of conventional tillage $(1 \mathrm{CT}, 2 \mathrm{CT})$, and one, two and three years of no-tillage (1NT, 2NT, 3NT). Error bars represent standard deviation $(\mathrm{n}=5)$. Figures followed by the same letter are not different (Tukey test, $p<0.05$ ).

\section{Equivalent Soil Layers}

Taking as a reference the $30 \mathrm{~cm}$ depth of $\mathrm{CE}$ soil, the equivalent soil layers in the study areas were used to calculate $\mathrm{C}$ and nutrient stocks and other fertility attributes. According to Equation 1, equivalent soil layers were $23.3,24.9,20.9,23.6$ and $20.3 \mathrm{~cm}$ in $1 \mathrm{CT}$, $2 \mathrm{CT}, 1 \mathrm{NT}, 2 \mathrm{NT}$ and $3 \mathrm{NT}$, respectively.

\section{Soil Carbon Stocks}

In the $\mathrm{CE}$ (reference) a C stock of $49 \mathrm{Mg} \mathrm{ha}^{-1}$ was calculated for the $0-30 \mathrm{~cm}$ soil layer (Figure 2). Bayer et al. (2006) reported a C stock of $54 \mathrm{Mg} \mathrm{ha}^{-1}$ in the $0-20 \mathrm{~cm}$ layer of a Typic Hapludox under cerrado. In a clayey Oxisol under cerrado stricto sensu a C stock of $61 \mathrm{Mg} \mathrm{C} \mathrm{ha}^{-1}$ was estimated for the 0 $30 \mathrm{~cm}$ soil layer (Resck et al., 2000). However, the soil bulk densities in these studies were higher than reported here, leading to higher $\mathrm{C}$ stocks.

Different land use practices had, overtime, altered soil $\mathrm{C}$ stocks (Figure 2). The $\mathrm{C}$ stock in 1CT $\left(47.6 \mathrm{Mg} \mathrm{ha}^{-1}\right)$ showed a decrease in relation to CE. Several studies have shown that the conversion of native cerrado through slash and burn followed by cultivation results in a decrease in $\mathrm{C}$ stocks and an associated increase in $\mathrm{CO}_{2}$ emissions (Detwiler, 1986; Brown \& Lugo, 1990; Lal, 2003; Franchini et al., 2007). However, in this study, the $C$ stock of the $2 \mathrm{CT}$ treatment increased to $55.4 \mathrm{Mg} \mathrm{ha}^{-1}$ in relation to CE, probably due to the enhanced supply of crop residues, decomposition of the cerrado root system and soil spatial variability.

Carbon stocks were $66.5,54.5$ and $67.5 \mathrm{Mg}$ $\mathrm{ha}^{-1}$ in $1 \mathrm{NT}, 2 \mathrm{NT}$ and $3 \mathrm{NT}$, respectively. The $1 \mathrm{NT}$ and $3 \mathrm{NT}$ areas had higher $\mathrm{C}$ stocks compared to $\mathrm{CE}$ and $1 \mathrm{CT}$. Improved agricultural practices have great potential to increase the $\mathrm{C}$ stocks in cropland soils (Bernardi et al., 2007). This was probably due to the absence of tillage operations (i.e., NT), leading to lower

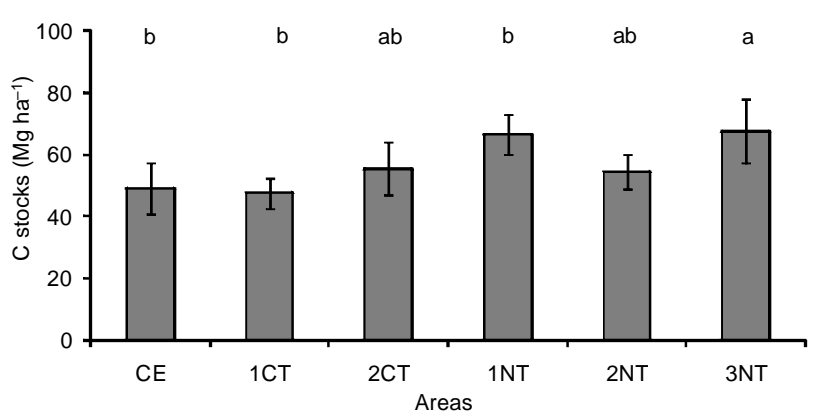

Figure 2 - Mean $\mathrm{C}$ stocks in the reference soil layer in cerrado (CE) and the equivalent soil layers after one and two years of conventional tillage (1CT, 2CT), and one, two and three years of no-tillage (1NT, 2NT, 3NT). Error bars represent standard deviation $(n=5)$. Figures followed by the same letter are not different (Tukey test, $p<0.05$ ). 
decomposition rates which favored the maintenance and accumulation of SOM (Bayer \& Mielniczuk, 1999; Resck et al., 2000; Green et al., 2007) and guaranteed a continuous flow of material and energy through the soil (Roscoe, 2005), leading to increased C stocks.

\section{Soil Nutrient Stocks}

A mean available $P$ stock of $9.3 \mathrm{~kg} \mathrm{ha}^{-1}$ was measured in the $0-30 \mathrm{~cm}$ soil layer under native cerrado vegetation (Figure 3 ). In $1 \mathrm{CT}$, the available $\mathrm{P}$ stock increased to $13.3 \mathrm{~kg} \mathrm{ha}^{-1}$ in relation to $\mathrm{CE}$, which could be the result of SOM mineralization following the burning of vegetation residues and $\mathrm{P}$ fertilizer application during planting. The burning of vegetation affects SOM mineralization due to the loss of energy, $\mathrm{C}, \mathrm{N}$ and $\mathrm{S}$ to the atmosphere and leads to the accumulation of $\mathrm{P}$, $\mathrm{K}, \mathrm{Ca}$ and $\mathrm{Mg}$ in the first five centimetres of soil (Coutinho, 1982).

After the introduction of the NT system associated with high $\mathrm{P}$ fertilizer application, available $\mathrm{P}$ stocks increased in the equivalent soil layers to 21.7, 32.1 and $68.4 \mathrm{~kg} \mathrm{ha}^{-1}$ for 1NT, 2NT and 3NT respectively. The increase made $3 \mathrm{NT}$ different from $\mathrm{CE}$ $(p<0.05)$ and all the other treatments apart from 2NT (Figure 3). It is possible that NT, which is associated with the maintenance of plant residues in the soil surface, caused improved $\mathrm{P}$ cycling, leading to an increase in available P stocks with increasing time under NT.

The absence of soil tillage diminishes clay mineral surfaces resulting in reduced $\mathrm{P}$ adsorption by $\mathrm{Fe}$ and $\mathrm{Al}$ oxides which leads to higher $\mathrm{P}$ availability and
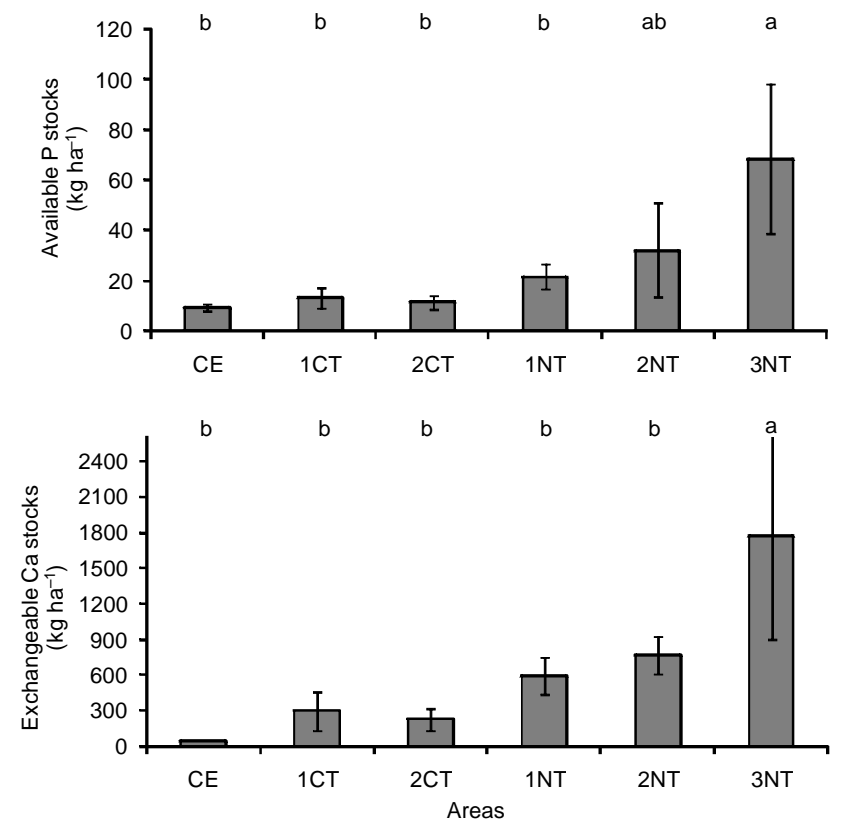

use efficiency under NT Addiscott \& Thomas (2000). Following several years of NT in Paraná State, Brazil, P fertilizer application was reduced by more than $50 \%$ to provide the same amount of plant available $\mathrm{P}$ (Gassen \& Gassen, 1996). It has been suggested that the supply of P fertilizer under NT is more efficient than under CT, due to higher soil water content (necessary for $\mathrm{P}$ diffusion) and higher SOM content on the soil surface. Due to lower $\mathrm{Al}^{3+}$ activity, $\mathrm{P}$ bonded to $\mathrm{SOM}$ is considered to be more soluble than clay mineral associated P (Thomas, 1986). However, in this study the high available P stocks under NT showed high spatial variability. Anghinoni \& Salet (1998) reported that when fertilizer is banded in the planting furrows, higher spatial variability of $\mathrm{P}$ and $\mathrm{K}$ occurs under NT compared to CT, mainly in the implementation phase of NT, which takes approximately five years.

Land use changes associated not only with new management practices (NT and CT), but also with lime and fertilizer applications were also found to increase exchangeable $\mathrm{K}, \mathrm{Ca}$ and $\mathrm{Mg}$ stocks in the soil when compared to native cerrado. Under NT, improved nutrient cycling due to higher crop residue inputs, periodic fertilizer application and the soil acidity correction associated with lower nutrient losses could be responsible for the increase in soil nutrient stocks, especially in 3NT. Calcium and Mg stocks had a similar trend (Figure 3). Despite the cultivated areas having received the same total amount of lime, the application rates were different, being split into several smaller applications in some cases. This could explain the in-
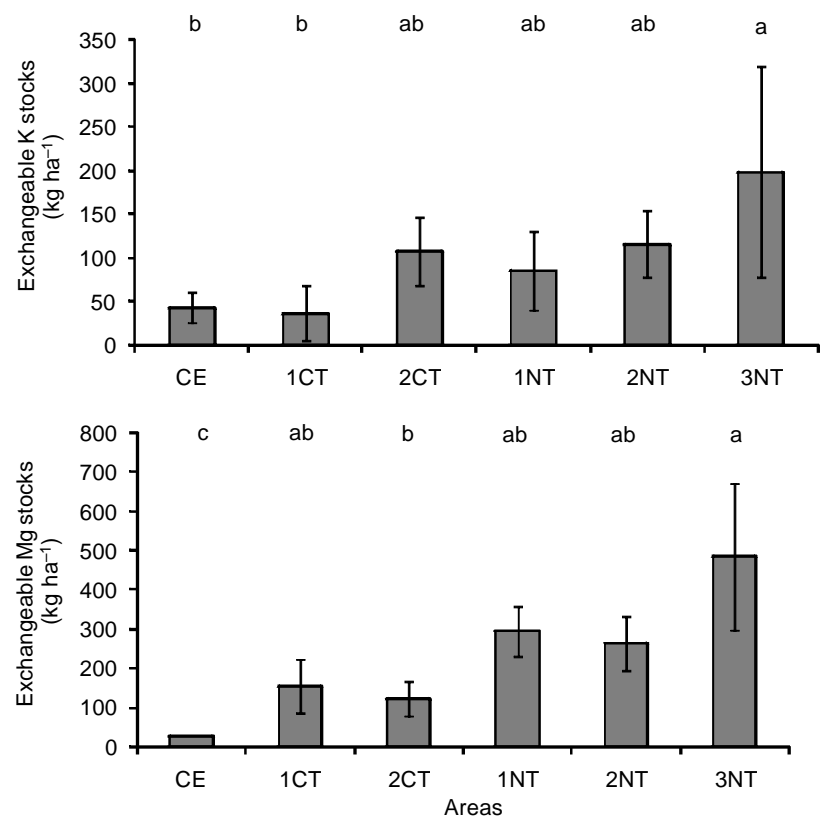

Figure 3 - Mean nutrient stocks (available P, exchangeable $\mathrm{K}, \mathrm{Ca}$ and $\mathrm{Mg}$ ) in cerrado (CE) and after one and two years of conventional tillage $(1 \mathrm{CT}, 2 \mathrm{CT})$, and one, two and three years of no-tillage (1NT, 2NT, 3NT). Error bars represent standard deviation $(\mathrm{n}=5)$. Figures followed by the same letter are not statistically significantly different using a Tukey test $(p<0.05)$. 
creases in soil $\mathrm{Ca}$ and $\mathrm{Mg}$ stocks and was probably due to split lime applications leading to a more efficient lime reaction in the soil (Table 1).

\section{Soil Acidity}

In $\mathrm{CE}$, mean $\mathrm{pH}$ in the $0-30 \mathrm{~cm}$ layer was 3.89 the lowest of all the chronosequence areas (Figure 4). After land use change, soil acidity correction and increasing exchangeable nutrient stocks, $\mathrm{pH}$ increased at the rate of about 0.25 unit for each year of cultivation. After five years (3NT), $\mathrm{pH}$ averaged 5.3 in the equivalent soil layer. Conversely, $\mathrm{H}^{+}+\mathrm{Al}^{3+}$ showed the opposite trend. At $3 \mathrm{NT}, \mathrm{H}^{+}+\mathrm{Al}^{3+}$ were reduced by half compared to the native cerrado soil giving an estimated annual reduction of $4.66 \mathrm{mmol}_{\mathrm{c}} \mathrm{dm}^{-3}$ of $\mathrm{H}^{+}+\mathrm{Al}^{3+}$ (Figure 4: $\mathrm{Y}=-4.66 \mathrm{X}+61.33)$.

\section{Cation Exchange Capacity and Base Saturation}

In contrast to the decline of $\mathrm{H}^{+}+\mathrm{Al}^{3+}$ over time, CEC increased over the cultivation period, indicating higher retention capacity for base cations. The high CEC in the CE suggests an effect of the high $\mathrm{H}^{+}$ $+\mathrm{Al}^{3+}$ content because potential acidity is added to the other measured cations in the equation used to calculate CEC. Moreover, lime and fertilizer applications associated with soil management practices substantially increased base saturation (V) in the equivalent soil lay- ers. Under the CE, the soil presented a negligible $\mathrm{V}$ of $4 \%$, the lowest value in the studied chronosequence. Liming and fertilizer application associated with NT management caused a minor loss of exchangeable cations and increased $\mathrm{V}$ in the soil. However, considering the practice of liming to raise $\mathrm{V}$ in the $20 \mathrm{~cm}$ soil layer in all cultivated areas to a desired value of $50 \%$, the adequate base saturation could only be maintained at 3NT, which represents the highest V compared to the other areas $(p<0.05)$ (Figure 5). This fact indicated that, despite the gradual accumulation of exchangeable cations in the soil, several years of soil acidity correction were necessary to obtain appropriate $\mathrm{V}$ conditions.

\section{Correlation among Carbon Stocks, Nutrient Stocks, and Other Soil Fertility Attributes}

A significant correlation between $\mathrm{C}$ and $\mathrm{P}$ stocks was determined in the $\mathrm{CE}(\mathrm{r}=0.81)$ indicating that soil $\mathrm{P}$ stock under cerrado is closely related to SOM. Despite increasing C and P stocks, the correlations between these stocks were not significant in the cultivated areas (Table 2). A possible reason may be a masking of the correlation by $\mathrm{P}$ fertilizer application as the main $\mathrm{P}$ source in these areas is $\mathrm{P}$ from fertilizer, not from SOM.
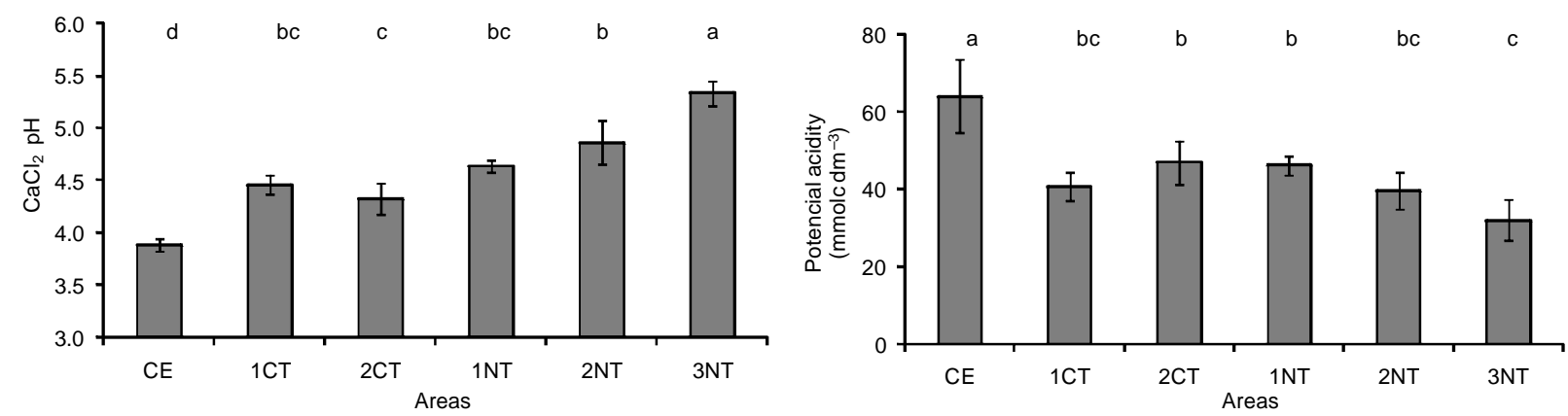

Figure 4 - Mean $\mathrm{pH}$ in $\mathrm{CaCl}_{2}$ and potential acidity at cerrado (CE) and after one and two years of conventional tillage (1CT, 2CT), and one, two and three years of no-tillage $(1 \mathrm{NT}, 2 \mathrm{NT}, 3 \mathrm{NT})$. Error bars represent standard deviation $(\mathrm{n}=5)$. Figures followed by the same letter are not different (Tukey test, $p<0.05$ ).
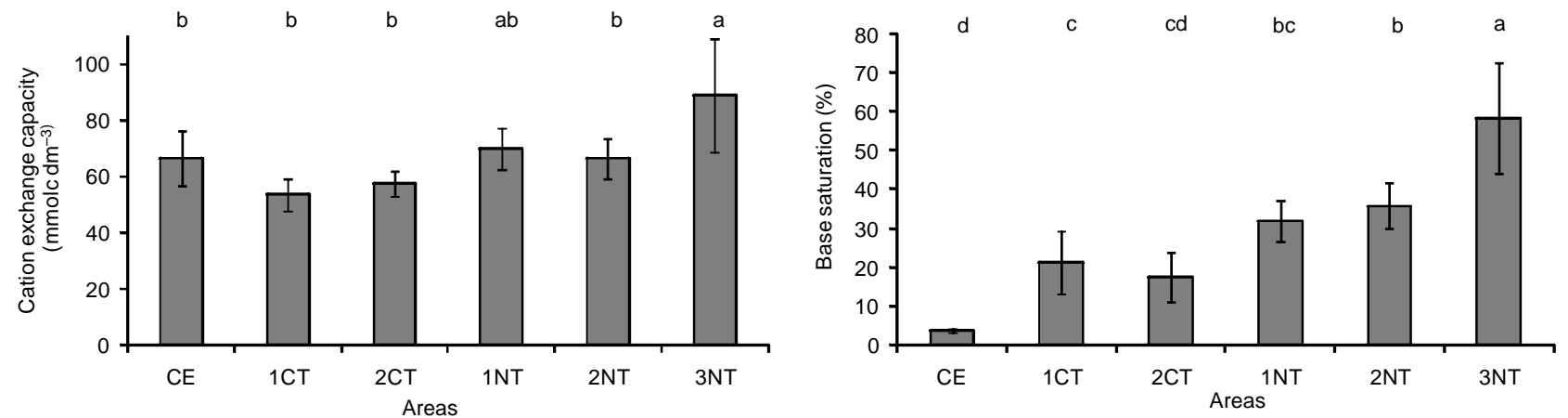

Figure 5 - Mean Cation Exchange Capacity (CEC) and Base Saturation (V) in cerrado (CE) and after one and two years of conventional tillage (1CT, 2CT), and one, two and three years of no-tillage (1NT, 2NT, 3NT). Error bars represent standard deviation $(\mathrm{n}=5)$. Figures followed by the same letter are not different (Tukey test, $p<0.05$ ). 
Table 2 - Pearsons' correlation coefficients between $\mathrm{C}$ stocks and nutrient stocks ( $\mathrm{P}, \mathrm{K}, \mathrm{Ca}$ and $\mathrm{Mg})$, soil acidity $\left(\mathrm{pH} \mathrm{CaCl}_{2}\right.$ and $\mathrm{H}+\mathrm{Al})$, cation exchange capacity $(\mathrm{CEC})$ and base saturation $(\mathrm{V})$ in equivalent soil layers.

\begin{tabular}{|c|c|c|c|c|c|c|}
\hline \multirow{2}{*}{ Attribute } & \multicolumn{6}{|c|}{ Areas $^{1}$} \\
\hline & $\mathrm{CE}$ & $1 \mathrm{CT}$ & $2 \mathrm{CT}$ & $1 \mathrm{NT}$ & $2 \mathrm{NT}$ & $3 \mathrm{NT}$ \\
\hline $\mathrm{C} \times \mathrm{P}$ & $0.81 *$ & $0.43^{\mathrm{ns}}$ & $-0.46^{\mathrm{ns}}$ & $0.27^{\mathrm{ns}}$ & $0.63^{\mathrm{ns}}$ & $0.56^{\mathrm{ns}}$ \\
\hline $\mathrm{C} \times \mathrm{K}$ & $0.82 *$ & $0.85^{*}$ & $-0.59^{\mathrm{ns}}$ & $-0.25^{\mathrm{ns}}$ & $0.56^{\mathrm{ns}}$ & $-0.21^{\mathrm{ns}}$ \\
\hline $\mathrm{C} \times \mathrm{Ca}$ & - & $0.11^{\mathrm{ns}}$ & $-0.67^{\mathrm{ns}}$ & $0.87 *$ & $0.99 * * *$ & $0.73^{\mathrm{ns}}$ \\
\hline $\mathrm{C} \times \mathrm{Mg}$ & - & $-0.04^{\mathrm{ns}}$ & $-0.80 *$ & $0.85^{*}$ & $0.84 *$ & $0.71^{\mathrm{ns}}$ \\
\hline $\mathrm{C} \times \mathrm{pH}$ & $-0.71^{\mathrm{ns}}$ & $0.11^{\mathrm{ns}}$ & $-0.62^{\mathrm{ns}}$ & $0.91 * *$ & $0.40^{\mathrm{ns}}$ & $0.82 *$ \\
\hline $\mathrm{C} \times \mathrm{H}+\mathrm{Al}$ & $0.91 * *$ & $0.64^{\mathrm{ns}}$ & $0.41^{\mathrm{ns}}$ & $0.73^{\mathrm{ns}}$ & $0.17^{\mathrm{ns}}$ & $-0.41^{\mathrm{ns}}$ \\
\hline $\mathrm{C} \times \mathrm{CEC}$ & $0.91 * *$ & $0.51^{\mathrm{ns}}$ & $-0.12^{\mathrm{ns}}$ & $0.88 * *$ & $0.86^{*}$ & $0.77^{\mathrm{ns}}$ \\
\hline $\mathrm{C} \times \mathrm{V}$ & $-0.34^{\mathrm{ns}}$ & $0.05^{\mathrm{ns}}$ & $-0.68^{\mathrm{ns}}$ & $0.86^{*}$ & $0.58^{\mathrm{ns}}$ & $0.77^{\mathrm{ns}}$ \\
\hline
\end{tabular}

$\mathrm{NB} 1 \mathrm{CT}$ and $2 \mathrm{CT}=$ one and two years Conventional Tillage with rice; 1NT, 2NT and 3NT = one, two, and three years No-Tillage with soybean after a 2-year period of rice under conventional tillage. ${ }^{1}$ referring to data in each area $(\mathrm{n}=5)$. ${ }^{\mathrm{ns}}$ not significant, $*, * *, * * *$ significance level for t-test at $p<0.1, p<0.05$ and $p<0.01$, respectively.

Stocks of $\mathrm{C}$ and $\mathrm{K}$ showed significant correlation $(\mathrm{r}=0.82, p<0.1)$ for the $\mathrm{CE}$, indicating a high interrelation between $\mathrm{K}$ and SOM in natural ecosystems which do not receive chemical fertiliser. Also, in 1CT there was a positive correlation between $\mathrm{C}$ and $\mathrm{K}$ stocks $(\mathrm{r}=0.85, p<0.1)$. Therefore, despite the lower exchangeable $\mathrm{K}$ stocks measured in these areas, the high positive correlations show high association of SOM and $\mathrm{K}$ in the soil. On the other hand, in areas where higher amounts of $\mathrm{K}$ fertilizer are applied no significant correlations between $\mathrm{C}$ and $\mathrm{K}$ stocks were found.

For $1 \mathrm{NT}$ and $2 \mathrm{NT}$ correlation coefficients of $\mathrm{r}=0.87(p<0.1)$ and $\mathrm{r}=0.99(p<0.01)$, respectively, were observed for $\mathrm{C}$ and $\mathrm{Ca}$ stocks. This was probably a result of continuous liming. However, a high correlation in $3 \mathrm{NT}$ was not significant and was possibly influenced by the interruption of liming in 2002-2003 (Table 1). The correlations between $\mathrm{C}$ and exchangeable $\mathrm{Mg}$ stocks showed the same trend as observed for $\mathrm{C}$ and $\mathrm{Ca}$, with the exception of a negative correlation $(\mathrm{r}=-0.80, p<0.1)$ in $2 \mathrm{CT}$.

Soil $\mathrm{pH}$ and $\mathrm{C}$ stocks were positively correlated not only in the 1NT $(\mathrm{r}=0.91, p<0.05)$ but also in the $3 \mathrm{NT}(\mathrm{r}=0.82, p<0.1)$. This may be due to soil acidity correction causing higher $\mathrm{pH}$ and plant productivity, consequently leading to increasing inputs of plant residues followed by higher SOM stocks. On the other hand, the correlation found in 2 NT was not significant. Although not significant, the negative correlation $(\mathrm{r}=-0.71)$ between $\mathrm{C}$ stock and $\mathrm{pH}$ in the $\mathrm{CE}$ is a testament to the high acidification level of tropical soils originating from SOM. This relation is associated with a significant positive correlation $(\mathrm{r}=0.92, p<$ 0.05 ) between the $\mathrm{C}$ stock and $\mathrm{H}^{+}+\mathrm{Al}^{3+}$. In the areas under cultivation, the correlations were not significant. This was probably influenced by liming, which causes desorption of $\mathrm{Al}^{3+}$ ions and adsorption of exchangeable base cations $(\mathrm{Ca}, \mathrm{Mg}$ and $\mathrm{K})$ to the exchange complex (Sá, 2001).

There were positive correlations between $\mathrm{C}$ stock and CEC in the CE $(p<0.05), 1 \mathrm{NT}(p<0.05)$ and 2NT $(p<0.1)$ with correlation coefficients $(\mathrm{r})$ of $0.91,0.88$ and 0.86 , respectively. The high correlation in $\mathrm{CE}$, in particular, indicates the important contribution of SOM to the CEC in tropical soils under native vegetation. These results are consistent with those of Raij (1969) and Silva et al. (1994) in terms of the fundamental importance of SOM for the CEC in variable charge soils under tropical climates. In these studies, SOM constitutes approximately $70-85 \%$ of the total CEC. The high correlations in NT also indicate an important contribution to the CEC. However, the CEC in CE is mainly occupied by $\mathrm{H}^{+}+\mathrm{Al}^{3+}$, whereas in the NT sites, CEC is mainly occupied by base cations.

A positive correlation between $\mathrm{C}$ stocks and $\mathrm{V}$ could only be verified in $1 \mathrm{NT}(\mathrm{r}=0.86, p<0.1)$. In the $\mathrm{CE}$ and $2 \mathrm{CT}$, non-significant negative correlations were found.

In summary, following the conversion of this Amazon cerrado to cultivated land the introduction of different crop management practices influenced soil C stocks and had direct and indirect consequences on other soil chemical attributes. Soil C stocks, (corrected for a mass of soil equivalent to the $0-30 \mathrm{~cm}$ layer under native vegetation) indicated that soils under NT generally showed higher $\mathrm{C}$ storage in comparison to native cerrado and $\mathrm{CT}$ soils. For instance, the mean $\mathrm{C}$ stock in $3 \mathrm{NT}$ was $18.5 \mathrm{Mg} \mathrm{ha}^{-1}$ higher than $\mathrm{CE}$ and $19.9 \mathrm{Mg} \mathrm{ha}^{-1}$ higher than 1CT. Under the NT system, 
higher crop residue inputs and a lack of soil disturbance are the driving forces behind $\mathrm{C}$ accumulation. However, the soybean-sorghum-millet rotation in the $2 \mathrm{NT}$ area which did not receive any $\mathrm{N}$ fertilizer application did not accumulate SOM to a sufficient degree to result in increased soil $\mathrm{C}$ stocks. At the same time, increasing available $\mathrm{P}$ and exchangeable $\mathrm{K}, \mathrm{Ca}$ and $\mathrm{Mg}$ stocks were measured under NT, mainly due to fertilizer application and soil acidity correction. A gradual reduction in potential acidity was apparent in the equivalent soil layers per cultivation year, while CEC increased simultaneously, indicating an increased proportion of base cations at the SOM exchange sites under NT. Conversely, the high CEC was accompanied by higher $\mathrm{H}^{+}+\mathrm{Al}^{3+}$ rates rather than by base cations in CE.

Positive correlations between C stocks and exchangeable $\mathrm{Ca}$ and $\mathrm{Mg}$ stocks were found under most NT areas, indicating an association between these lime components and SOM after NT was introduced. There was a high correlation between $\mathrm{C}$ stocks and CEC, $\mathrm{V}$ and $\mathrm{pH}$. Conversely, the positive correlation between $\mathrm{C}$ stocks and CEC in the CE indicates an important contribution of SOM to CEC in tropical soil under native vegetation. However, at $\mathrm{CE}$ the exchange sites were mainly occupied by $\mathrm{H}^{+}+\mathrm{Al}^{3+}$ rather than by base cations, as corroborated by the positive correlation between $\mathrm{C}$ stock and total acidity. $\mathrm{P}$ and $\mathrm{K}$ stocks only had positive correlations with $\mathrm{C}$ stocks in $\mathrm{CE}$, indicating the high association of $\mathrm{P}$ and $\mathrm{K}$ with SOM in natural ecosystems. Despite high $\mathrm{C}$ stocks and high $\mathrm{P}$ and $\mathrm{K}$ stocks in the study areas, the relationships between $\mathrm{C}$ and $\mathrm{P}$ and $\mathrm{K}$ were not significant and were probably masked by $\mathrm{P}$ and $\mathrm{K}$ fertilizer effects. Phosphorus and $\mathrm{K}$ are typically applied to the planting furrows which can lead to high spatial variation of these elements in the soil. It was concluded that the main source of these elements was fertilizer application, rather than SOM.

\section{ACKNOWLEDGEMENTS}

To Fundação de Amparo à Pesquisa do Estado de São Paulo (FAPESP) for supporting this work by research grant FAPESP Proc. no. 04/01230-0 and to Dr. Eleanor Milne for the review and interesting suggestions. We also thank the owners of Fazenda União for all the support given during this study.

\section{REFERENCES}

ADDISCOTT, T.M.; THOMAS, D. Tillage, mineralization and leaching: phosphate. Soil \& Tillage Research, v.53, p.255273,2000 .
ANGHINONI, I.; SALET, R.L. Amostragem do solo e as recomendações de adubação e calagem no sistema plantio direto. In: NUERNBERG, N.J. (Ed.) Conceitos e fundamentos do sistema plantio direto. Lages: Sociedade Brasileira de Ciência do Solo, 1998. p.27-52.

BAYER, C.; MARTIN-NETO, L.; MIELNICZUK, J.; PAVINATO, A. Armazenamento de carbono em frações lábeis da matéria orgânica de um Latossolo Vermelho sob plantio direto. Pesquisa Agropecuária Brasileira, v.39, p.677-683, 2004.

BAYER, C.; MARTIN-NETO, L.; MIELNICZUK, J.; PAVINATO, A.; DIECKOW, J. Carbon sequestration in two Brazilian cerrado soils under no-till. Soil \& Tillage Research, v.86, p 237-245, 2006.

BAYER, C.; MIELNICZUK, J. Características químicas do solo afetadas por métodos de preparo e sistemas de cultura. Revista Brasileira de Ciência do Solo, v.21, p.105-112, 1997.

BAYER, C.; MIELNICZUK, J. Dinâmica e função da matéria orgânica. In: Santos, G.A., Camargo, F.A.O. (Ed.) Fundamentos da matéria orgânica do solo: ecossistemas tropicais e subtropicais. Porto Alegre: Gênesis, 1999. p.1-26.

BERNARDI, A.C.C.; MACHADO, P.L.O.A.; MADARI, B.E.; TAVARES, S.R.L.; CAMPOS, D.V.; CRISÓSTOMO, L.A. Carbon and nitrogen stocks of an arenosol under irrigated fruit orchards in semiarid Brazil. Scientia Agricola, v.64, p.169-175, 2007.

BERNOUX, M.; ARROUAYS, D.; CERRI, C.C.; BOURENNANE, H. Modelling vertical distribution of carbon in Oxisols of the Western Brazilian Amazon (Rondônia). Soil Science, v.163, p.941-951, 1998.

BERNOUX, M.; CERRI, C.C.; CERRI, C.E.P., SIQUEIRA NETO, M.; METAY, A., PERRIN, A.S.; SCOPEL, E.; BLAVET, D.; PICCOLO, M.C.; PAVEI, M.; MILNE, E. Cropping systems, carbon sequestration and erosion in Brazil, a review. Agronomy for Sustainable Development, v.26, p.1-8, 2006.

BROWN, S.; LUGO, A.E. Effects of forest clearing and succession on the carbon and nitrogen contents of soil in Porto Rico and U.S. Plant and Soil, v.124, p.53-64, 1990.

BUSTAMANTE, M.M.C.; MEDINA, E.; ASNER, G.P.; NARDOTO, G.B.; GARCIA-MONTIEL, D.C. Nitrogen cycling in tropical and temperate savannas. Biogeochemistry, v.79, p.209-237, 2006.

CARVALHO, J.L.N.; CERRI, C.E.P.; CERRI, C.C.; FEIGL, B.J. ; PICCOLO, M.C.; GODINHO, V.; HERPIN, U. Changes of chemical properties in an Oxisol after clearing of native cerrado vegetation for agricultural use in Vilhena, Rondônia State, Brazil. Soil \& Tillage Research, v.96, p.95-102, 2007.

CERRI, C.E.P.; COLEMAN, K.; JENKINSON, D.S.; BERNOUX, M.; VICTORIA, R.; CERRI, C.C. Modeling soil carbon from forest and pasture ecosystems of Amazon, Brazil. Soil Science Society of America Journal, v.67, p.1879-1887, 2003.

CERRI, C.E.P.; SPAROVEK, G.; BERNOUX, M.; EASTERLING, W.E.; MELILLO, J.M.; CERRI, C.C. Tropical agriculture and global warming: impacts and mitigation options. Scientia Agricola, v.64, p.83-99, 2007.

CORAZZA, E.J.; SILVA, J.E.D.; RESCK, D.V.S.; GOMES, A.C. Comportamento de diferentes sistemas de manejo como fonte ou depósito de carbono em relação à vegetação de cerrado. Revista Brasileira da Ciência do Solo, v.23, p.425-432, 1999.

COUTINHO, L.M. Ecological effects of fire in Brazilian cerrado. In: HUNTLEY, B.J.; WALKER, B.H. (Ed.) Ecology of tropical savannas. New York: Springer, 1982. 273-291p.

DA VEIGA, M.; HORN, R.; REINERT, D.J.; REICHERT, J.M. Soil compressibility and penetrability of an Oxisol from southern Brazil, as affected by long-term tillage systems. Soil \& Tillage Research, v.92, p.104-113, 2007.

DETWILER, R.P. Land use change and the global carbon cycle: the role of tropical soils. Biogeochemistry, v.2, p.67-93, 1986.

ELLERT, B.H.; BETTANY, J.R. Calculation of organic matter and nutrients stored in soils under contrasting management regimes. Canadian Journal of Soil Science, v.75, p.529-538, 1996. 
EMPRESA BRASILEIRA DE PESQUISA AGROPECUÁRIA EMBRAPA. Manual de métodos de análise do solo. Rio de Janeiro: SNLCS, 1979. 58 p.

FRANCHINI, J.C.; CRISPINO, C.C.; SOUZA, R.A.; TORRES, E.; HUNGRIA, M. Microbiological parameters as indicators of soil quality under various soil management and crop rotation systems in southern Brazil. Soil \& Tillage Research, v.92, p.18-29. 2007.

FREITAS, P.L.; BLANCANEAUX, P.; GAVINELLI, E.; LARRELARROUY, M.C.; FELLER, C. Nível e natureza do estoque orgânico de Latossolos sob diferentes sistemas de uso e manejo. Pesquisa Agropecuária Brasileira, v.35, p.157-170, 2000.

GASSEN, D.; GASSEN, F. Plantio direto, o caminho do futuro. Passo Fundo: Aldeia Sul, 1996. 207p.

GREEN, V.S.; STOTT, D.E.; CRUZ, J.C.; CURI, N. Tillage impacts on soil biological activity and aggregation in a Brazilian cerrado Oxisol. Soil \& Tillage Research, v.92, p.114-121, 2007.

KÖPPEN, W. Versuch einer Klassification der Klimate, vorzugsweise nach ihren Beziehungen zur Pflanzenwelt. Geographische Zeitschrift, v.6, p.593-611, 657-679, 1900.

LAL, R. Global potential of carbon sequestration to mitigate the greenhouse effect. Critical Reviews in Plant Sciences, v.22, p.151-184, 2003.

MORAES, J.F.L.; VOLKOFF, B.; CERRI, C.C.; BERNOUX, M. Soil properties under Amazon forest and changes due to pasture installation in Rondônia, Brazil. Geoderma, v.70, p.63-81, 1996.

NELSON, D.W.; SOMMERS, L.E. Total carbon, organic carbon and organic matter. In: PAGE, A.L.; MILLER, R.H.; KEENEY, D.R. (Ed.) Methods of soil analysis: chemical and microbiological properties. 2 ed. Madison: American Society of Agronomy, 1982. p.539-579

OLIVEIRA, O.C.; OLIVEIRA, I.P.; URQUIAGA, S.; ALVES, B.J.R; BODDEY, R.M. Chemical and biological indicators of decline/ degradation of Brachiaria pastures in the Brazilian cerrado. Agriculture, Ecosystems and Environment, v.103, p.289$300,2004$.

RAIJ, B. van. A capacidade de troca de cátions das frações orgânica e mineral dos solos. Bragantia, v.28, p.85-112, 1969.
RAIJ, B. van.; QUAGGIO, J. A. Métodos de análise de solo para fins de fertilidade. Campinas: Instituto Agronômico de Campinas, 1983. 16p. (IAC Circular, 63).

RESCK, D.V.S.; VASCONCELLOS, C.A.; VILELA, L.; MACEDO, M.C.M. Impact of conversion of Brazilian cerrado to cropland and pasture land on soil carbon pool and dynamics. In: LAL, R.; KIMBLE, J.M.; STEWART, B.A. (Ed.) Global climate change and tropical ecosystems. Boca Raton: CRC Press, 2000. p.169-196.

RIBEIRO, J.F.; WALTER, B.M.T. Fitofisionomias do bioma Cerrado. In: SANO, S.M.; ALMEIDA, S.P. (Ed.) Cerrado: ambiente e flora. Brasília: EMBRAPA, 1998. p.89-166.

ROSA, M.E.C.; OLSZEVSKI, N.; MENDONÇA, E.S. Formas de carbono em Latossolo Vermelho Eutroférrico sob plantio direto no sistema biogeográfico do cerrado. Revista Brasileira de Ciência do Solo, v.27, p.911-923, 2003.

ROSCOE, R. Dinâmica da matéria orgânica em solos de cerrado. In: CONGRESSO BRASILEIRO DE CIÊNCIA DO SOLO, Recife, 2005. Anais. Recife: SBCS, 2005. CD-ROM

ROSCOE, R.; BUURMAN, P. Tillage effects on soil organic matter in density fractions of a cerrado Oxisol. Soil \& Tillage Research, v.70, p.107-119, 2003.

SÁ, J.C.M. Dinâmica da matéria orgânica do solo em sistemas de manejo convencional e plantio direto. Piracicaba: USP/ESALQ, 2001. 141 p. (Doutorado).

SAS INSTITUTE. SAS/STAT user's guide: version 6. 4 ed. Cary: SAS Institute, 1989. v.2, 846p.

SILVA, J.E.; LEMANSKI, J.; RESCK, D.V.S. Perdas de matéria orgânica e suas relações com a capacidade de troca de catiônica em solos da região de Cerrados do oeste baiano. Revista Brasileira de Ciência do Solo, v.18, p.541-547, 1994.

THOMAS, G.W. Mineral nutrition and fertilizer placement. In: SPRAGUE, M.A.; TRIPLETT, G.B. No-tillage and surfacetillage agriculture: the tillage revolution. New York: John Wiley, 1986. p.1-18.

Received October 01, 2007

Accepted August 26, 2008 